\title{
Earthquake weather and other tentative correspondences
}

\author{
Laura McLauchlan and Sarah Treadwell
}

The term 'earthquake weather' has had a fluctuating history, being understood as both an observable event and a recurring fiction. The starting point for the term is usually associated with Aristotle, who is said to have promoted the idea that winds trapped in underground caves caused earthquakes. Southern Californian conceptualisations of earthquake weather are recognised in New Zealand as early as 1851 and typically emphasise the "heavy oppressive feeing in the air; heat, calm, little cloud and more or less haze” (1919, 10 May). In New Zealand reports of earthquakes, such explicit ideas of 'earthquake weather' are generally regarded with suspicion. Despite the public dismissal of 'earthquake weather', however, earthquake reports frequently link seismic activity with carefully detailed weather conditions, giving expression to atmospheres both meteorological and affective. While these reports demonstrate a tentative hypothesising of earth and weather connection, in the light of Hélène Cixous's écriture féminine these writings re-emerge as poetics of moment. Enforced, in many ways, by earthquakes' own resistance to domination, this lightness of approach gives space to atmospheres of unpredictability, in which earth and weather are reformed as mutually responsive possibilities.

Shortly after a relatively substantial earthquake in Wellington (January 20, 2014), the taxi driver taking me to a funeral in heavy rain, in conversation remarked on the weather on the day of the earthquake. It was very still, he said, and uncanny, he implied. The rain driving onto the windscreen is commonplace in a city through which the winds of the world circulate, while the limpid humidity of the previous day was recalled by the driver as premonition. Airborne droplets of water smearing across the glass rendered the local landscape blurry and uncertain. Through the lens of weather, the visual solidity of earthquake-prone ground was undone.

Earthquakes induce an uncertainty that cannot be entirely pictured by the zigzagging tremor of the seismograph, compelling though these are. The black lines displayed on Geonet and the like seem remarkably authoritative, though the written record of every small earthquake event that follows a quake of substance becomes an absurd list running into the thousands. The volume of shakes balloons out, and the science of the very certain record seems suspect in its proliferating detail. Assurance vanishes when the ground is a trembling liquid, when balance is unreliable and premonitions disturbingly follow the event; the black lines of the earthquake graphs need a supplement to register the uncertainty induced by imaginative escalations of disaster.

The images that accompany the writing in this paper offer a register of indeterminate atmosphere, collecting those parts of architecture and landscape that are in some ways resistant to written narrative or concrete description. While emotional colouration, dematerialisation and surface effects might be productively approached through ekphrastic writing, there is still a residual gap between the formal approximations of images and linear, sequential constructions of writing.

Informed by traditions of both architectural drawing and writing, the images are sequential, suppressed in hue and constructed of repetitive marks. Interleavings, bastard echoes; they are involutions that enact atmospherics of earthquake weather. A stuttering flow of matter and meaning, constructed from particles of earth, oil and water, lithographs and watercolours, the images are digitally layered. While architectural drawings approximate acts of building, seeking stability on the grounds of the page, and imagining stability in building foundations, the drawings here serve a parallel intent to the text; they rehearse earthquake weather, replicating the indeterminate space that is the surface and atmosphere of the globe, the site of both atmospheric and geological upheavals. Earthquake weather drawings seek to create disturbances and conjunctions, recalling the material repulsions and 
attractions from which they are formed. Hélène Cixous, writing on Roni Horn and weather, points to the "elusive strangeness of the character called Weather, calm to look at, a calm which by its name promises a storm. Weather lightly, calmly androgynous, undecidable.” (Cixous 2012: 77)

\section{Earthquake atmospheres}

The recognition of atmosphere, as both the subject matter of architecture and as a key site of experience more broadly, owes much to the work of Gernot Böhme. Böhme approaches atmosphere as a space with a mood - a tuned space which has a tendency to tune those within it. Such spaces are never voids: as Böhme (2013) notes, atmospheres are also shaped, or even created, by elements such as light, smell, and sound. Despite our attempts at insulation from it, weather, in all its forms, changes space and co-creates atmospheres (see Hill 2012). Thus, weather moves between meteorological and metaphoric definitions of atmosphere, being both the subject of pre-eighteenth century understandings of atmosphere as "the earth's envelope of air which carries the weather" (Böhme 2013: 2) and a major co-creator of atmospheres in a post-eighteenth century sense of "moods which are 'in the air", or "the emotional tinge of a space" (2).

Within New Zealand and other earthquake-prone nations, the influence of the weather on the mood-atmospheres of our lives is not limited to the conditions of the air - whether cloud, wind, moisture, or pressure - but extends to the flux of the very earth itself. From the 1850s until the early 20th century, a series of curious newspaper reports were published in New Zealand, in which movements of the earth were coupled with carefully detailed descriptions of weather. Some aspects recurred in these hundreds of often poetic, somewhat (and variously) cryptic, reports.

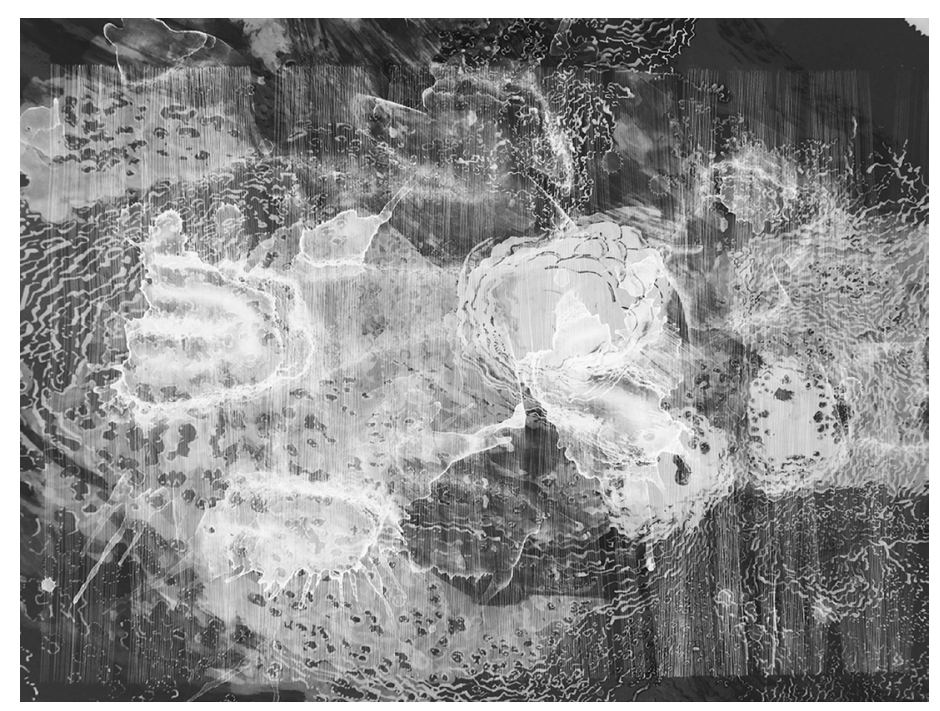

Fig. 1 In a photograph published shortly after the 2011 earthquake in Christchurch (2011: $n p$ ) the city is shown enveloped in a dusty whiteness, shimmering evidence of disintegrating ground and dissolving buildings. A pale ocular blur in an otherwise clear image. Ripples of air and matter, recorded delicately in residual grit. Lines that match the earth's movement have become sticky, magnifying and distorting careful records, thickening the implacable beat of seismic measurement. A moment of milky air and liquefying earth detailed.

For example, from The Star, in 1885: "A smart shock of earthquake occurred at 10 minutes past 6, vibration north to south, and lasting nine or ten seconds. It was followed by a slighter shock half a minute afterwards. The weather is gloomy and threatening.” (1885, January 16) 
And then, from the Otago Daily Times, in 1902: "A sharp shock of earthquake was experienced at 10 minutes to 11 to-night at Gisborne. Recent weather has been strong, cold, and north-westerly, but only an occasional shower has fallen. A dead calm set in before the earthquake” (1902, May 17).

These reports are typical in both the close association of earth and weather movements, and in their seeming reluctance to openly hypothesise earth-weather relationships. The suggestion of earthquake weather correspondences is tantalisingly implicit. Does the "dead calm", or the "threatening" gloom, suggest suspicion of a deeper causal structure lying behind both the dread-filled weather and the earthquake? More specifically suggestive of a notion of earthquake weather, references to "unusual" weather conditions accompanying earthquakes appear throughout these reports, including: "an unusually long spell of hot weather"; "a peculiar stillness in the air, the weather being very close" (1885, September 5); an "exceptionally heavy storm ... after the long period of dry weather" (1902, April 9); and "somewhat cloudy ... very unusual for the season" (1855, November 21).

Occasionally, weather conditions are explicitly identified as unusual for earthquakes, as in this item from the Press in 1894:

WELLINGTON, April 2. A smart shock of earthquake was felt at 1.41 a.m. to-day. A strong Southerly gale with rain was blowing at the time. This is the second occasion recently that an earthquake has been felt in bad weather, which is a most unusual occurrence. (1894, April 3)

Concomitant with a notion of the coincidence of certain weathers and earthquakes as "unusual" is the existence of an expected and related mode of weather-earthquake - though the nature of this relationship is not expressed directly. At times, it becomes one of identity, in which earth and weather movement are considered all-at-once, challenging elemental boundaries. In the Otago Daily Times, we find in 1907:

WANGANUI, April 18. The weather conditions were very mixed to-day. The morning and afternoon were beautifully fine. An earthquake was felt at 4.45 p.m., and a thunderstorm, with vivid lightning and downpour, took place at 6.45 p.m. Then the atmosphere suddenly cleared and the night was perfect. (1907, April 20)

Alongside watches, compasses, thermometers and, occasionally, barometers, bodies are vital instruments for measuring and interpreting earthquakes. Reporters' bodies seem to be possessed by trepidations of doom and threat, dead-calm and perfect. The language of these reports, suggesting a bodily apprehension of earth and weather movements, acknowledges the shaping of experience by ephemeral and apparently immaterial conditions; we read of atmosphere as both meteorological and metaphoric. Oddly, for such a public medium as the newspaper, the reader may even be invited into the intimate earth-weather atmospheres through which a correspondent experiences earthquakes; located in weather, reporters become momentarily full, vulnerable, weathered humans, like Thomas Arnold in 1848.

\section{Weather as mood-atmosphere}

Alongside their careful attention to weather and earth, earthquake correspondents reveal a distinct, and perhaps surprising, wariness of existing earthquake weather theories. Explicit mention of "earthquake weather" occurs only occasionally in New Zealand reports and, when it does, it is typically with trepidation. For example, a 1893 letter to the editor states that "there seems to be no particular weather belonging to an earthquake" before adding, somewhat mysteriously, "[b]ut few can judge this" (1893, February 23). The author of an astronomical report in the Wairarapa Daily 
Times noted that, while "[w]e sometimes hear of 'earthquake weather,' it is, however, extremely improbable that an earthquake can affect the weather before it happens" (1909, February 5). Precisely what is meant by "earthquake weather" in these contexts appears to differ slightly from the Californian idea of earthquake weather, which typically emphasises, "heat, calm, little cloud and various degrees of haze" (1918, December 17). A visitor to Wellington in 1904 writes:

One hears much about earthquake weather, the popular idea being that weather muggy, windy and oppressive is the kind which brings earthquakes. Let this be changed: the day was the finest of the season, bright, crisp, with a light breeze and an atmosphere of champagne; and on that most remarkable day we have had the most remarkable earthquake. Those who believe in the connection between the weather and earthquakes have an obvious conclusion before them.” (1904, August 10)

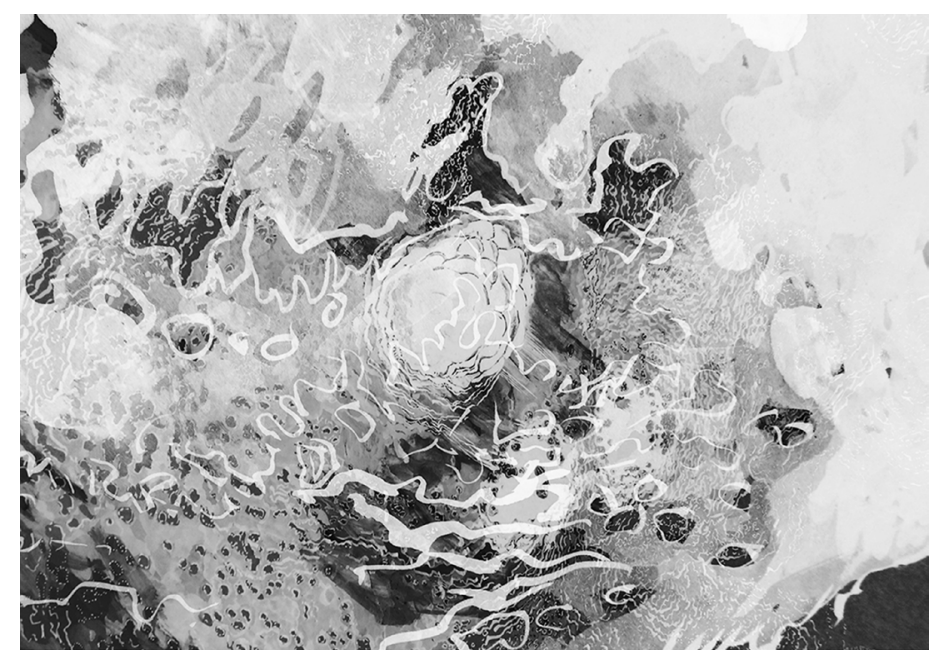

Fig. 2 Thomas Arnold in Wellington, North Island, New Zealand: "On the night of the 16th October, between one and two, A.M., the whole household was roused from sleep by the shock of an earthquake. It seemed to me in my dreams that a storm of wind was blowing - that it blew harder and harder - that it shook the very house under which impression I awoke and found myself indeed being rocked violently from side to side in my bed, like an infant in the cradle, not however by the powers of the air, but by the mysterious forces pent up within the breast of the earth.... The sensation produced was singular and awful, its chief element being the feeling of utter insecurity, when that which we familiarly think of as the firm and solid earth was thus heaving and rolling beneath us.” (1861: 254)

An article in The Lyttelton Times, in 1851, even identifies earthquake weather as a term used by "old settlers” (1851, August 2).

Though earthquake weather associations were often treated with some degree of suspicion, reports detailing earthquakes in relation to the weather were relatively commonplace in New Zealand newspapers up until the 1910s. There are, however, very few after the 1920s. One reason for this decline might be the emergence of psychological explanations for the apparent correlation of earthquake and weather. An article citing a Professor Humphreys of the United States Weather Bureau dismisses the notion of earthquake weather as being of "psychological origin" (1919, 10 May). This article was widely published in New Zealand, throughout the country, appearing in at least nine papers in 1918 and 1919. Referring to a Californian understanding that earthquake weather is marked by a heavy oppressive feeing in the air, the article argued that such weather, "inclines us to sharper observation of earthquake disturbances and accentuates the impression they make on our 
senses; thus we retain more vivid memories of the quakes occurring during such weather than of those occurring on more soothing days" (1919: 10).

Professor Humphrey argues that such thinking-in-weather is unreliable, conceiving of the influence of the weather as a sort of trickery. However, humans are not hermetically sealed. Böhme writes that, "[s]pace is genuinely experienced by being in it, through physical presence" (2005: 402). Through our physical presence, we participate in a space through the "affective tendency by which our mood is attuned to the nature of a space, to its atmosphere" (402-3). In this light, earthquake weather correspondences shift; we are no longer reading unreliable attempts at correlating earthquakes and weather but are, instead, invited into the intimacy of correspondents' descriptions of the affective atmospheres of weather and material movement.

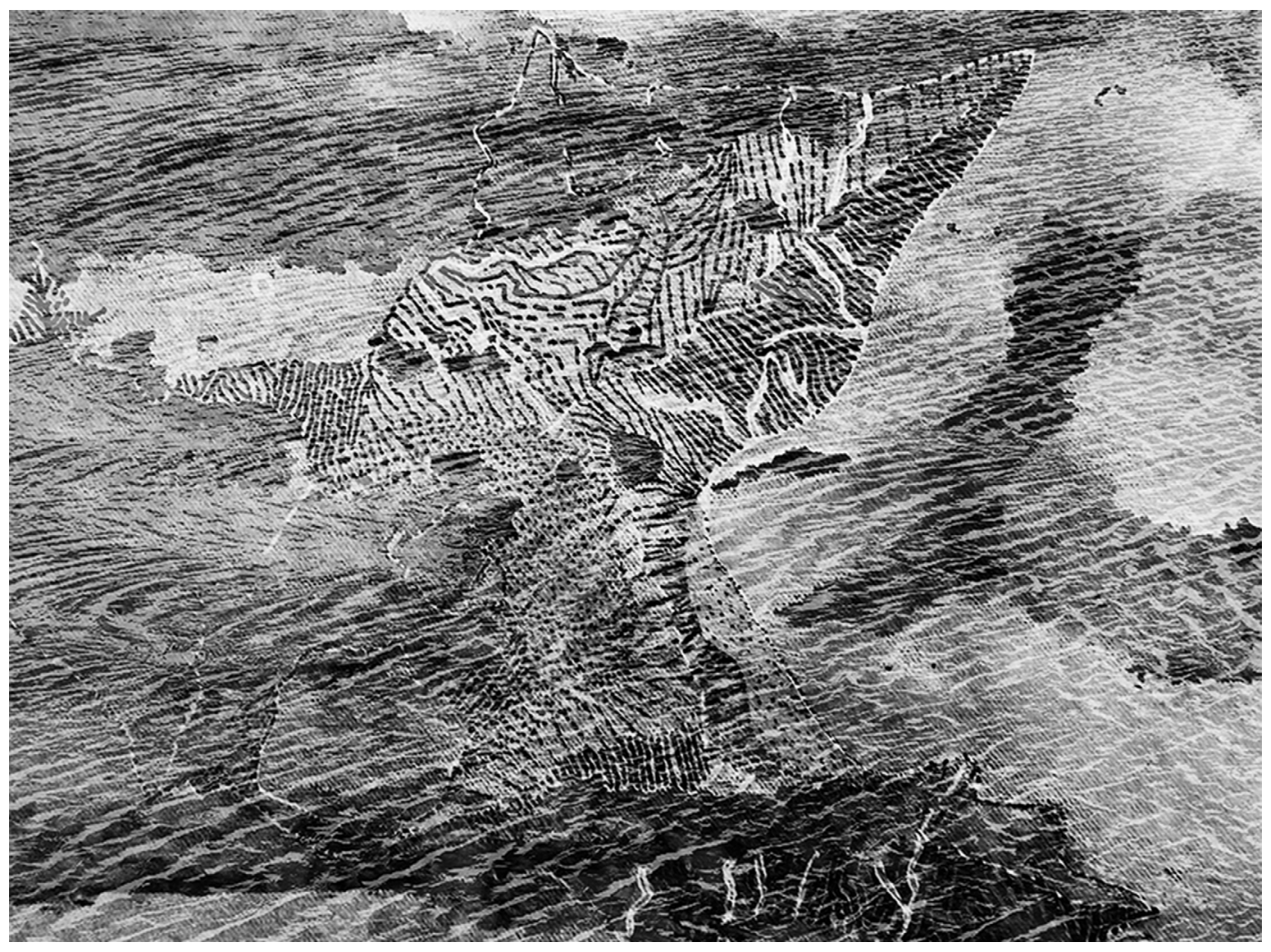

Fig. 3 The Lyttelton Times reported in 1855: "Two shocks of earthquake were distinctly felt in Lyttelton last night at about the hours of 9 and 12 'clock, and another this morning at about 7 o'clock. Several people mention having felt other minor shocks during the night. None of them were violent, but the first was of longer duration than any we have yet experienced here. Several pendulum clocks were stopped by the motion. Many old settlers say that they do not remember an earthquake before of such long duration in New Zealand. The wind was blowing in strong gusts from the N.W., and has continued in that quarter ever since, the weather being oppressive and sultry. We have just heard the first shock at Christchurch was felt very severely.”(1855, January 24)

Joan Didion, writing of the Santa Ana wind in Los Angeles, illustrates the ways in which weather is inextricably connected to mood-atmospheres. She describes one such instance:

I have neither heard nor read that a Santa Ana is due, but I know it, and almost everyone I have seen today knows it too. We know it because we feel it. The baby frets. The maid sulks. I rekindle a waning argument with the telephone company, then cut my losses and lie down, given over to whatever it is in the air. To live with the Santa Ana is to accept, consciously or unconsciously, a deeply mechanistic view of human behavior. (2008: 217$)$ 
Didion goes on to describe a Santa Ana period:

The Pacific turned ominously glossy ... one woke in the night troubled not only by the peacocks screaming in the olive trees but by the eerie absence of surf. The heat was surreal. The sky had a yellow cast, the kind of light sometimes called 'earthquake weather.' My only neighbor would not come out of her house for days, and there were no lights at night, and her husband roamed the place with a machete. One day he would tell me that he had heard a trespasser, the next a rattlesnake.

(2008: 217)

A wind may, indeed, activate the experience of earthquakes, rattle snakes, and trespassers more keenly. In Didion's text, and in our earthquake correspondents' reports of atmosphere, we are given something like an anamnesis of a moment of atmosphere; collectives of experience are offered in explanation of the present. Through giving space to possible, yet potentially unprovable, correspondences, unexpected traces of the moment emerge. As with anamneses, pre-editing our experience may lead to the loss of a vital unknown. Yet, despite the importance of the weather to our experience of the world, it seems too often to be omitted from our discussions of experience. Anthropologist Tim Ingold, for example, has noted that his carefully detailed observations of his own experience of weather during fieldwork would always fall out as he moved from fieldnotes to academic publication - despite his ethnographic focus on weather experiences of others. Such is the difficulty of theorising humans in weather. Yet, what is lost through imposing theories of relevance upon our experience?

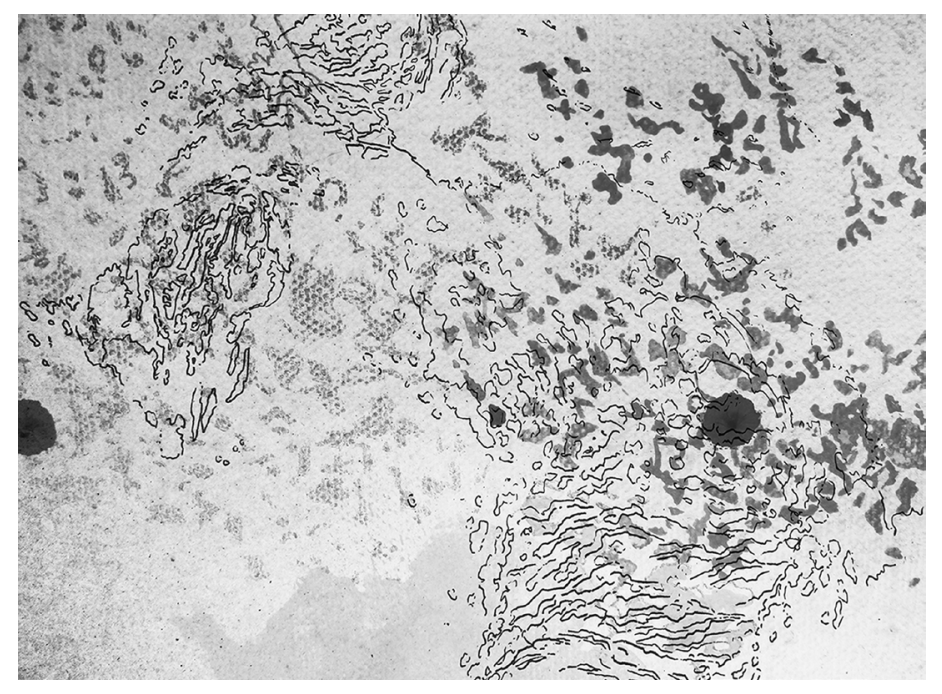

Fig. 4 “Though Professor Nowaek's scheme of forecasting weather and seismic disturbances by weather plants obtained from Cuba, has aroused a good deal of interest, scientific circles have been sceptical. He has a theory that earthquakes and eruptions are not isolated happenings, but are all more or less in sympathy, and in certain lines of direction. These lines he has traced on a chart of the world. On another chart he has drawn lines based upon observations of barometric pressures and sun spots. He lays the second chart over the first ...” (1908, 8 December)

\section{Atmospheres of unpredictability: humility and colonial will}

Within the atmospheres painted by the correspondents, earthquakes lead to the relocation of the earth within weather; and, like the weather, earthquakes evade prediction. Architect and designer Elizabeth Diller, writing about the Blur project, points out that, contemporary culture "is addicted to weather information ... Our cultural anxiety about the weather can be attributed 
to its unpredictability" (2001: 132). Throughout the earthquake weather reports, the earth is frequently considered along with the weather, forming a more entire realm of Diller's atmosphere of unpredictability. Earthquake and weather "prophecy" are equally based in guess-work; thus, the Oamaru Mail states in 1905: "The earthquake is like the wind in the parable - it bloweth whither it listeth. Particularly one cannot tell whence it cometh" (1905: 4).

In these reports, then, the mood-atmospheres of the weather incorporate the movement of the earth, troubling the indeterminate atmospheric divide between stability and movement, causing us to consider, momentarily at least, the earth within the moving atmosphere, within weather. Ingold urges us to recognise the co-creation of earth and air, where plants pull weather down into the soil via their leaves, and where winds, moisture and sun ensure that the ground's surface is never stable but, rather, continuously generated and degenerated. In the face of this flux and responsiveness, the creation of any clear interface between the two requires great effort and constant maintenance (Ingold 2010: S126). Both earth and sky constantly challenge the hard and resistant layers of concrete and asphalt which, Ingold argues, attempt "to convert the ground into the kind of surface that theorists of modernity always thought it was - level, homogeneous, pre-existent and inert” (2008: 1808-9). Earthquakes most urgently rupture such surfacings.

A humility arises from this failure of mastery over nature. The following report, from the Star in 1868, suggests that humility in the face of earthquakes is not specific to New Zealand:

AN EARTHQUAKE IN ENGLAND. (From the Times, Nov. 2.) Shortly after half-past ten on the night of Oct. 30, a distinct shock of earthquake was felt in many places in the West of England, and in South Wales. Reports were brought into Worcester in the course of Saturday from different towns and villages westward, describing the shock in very similar terms. It is a fact, though it may have nothing to do with these phenomena, that up to the time of the shock the weather was cold, but the thermometer rose fifteen degrees on Saturday. (1868, December 24)

The comment that the sudden warmth "may have nothing to do with these phenomena" is indicative of the shy persistence of earthquake weather associations. Although reluctant to state any causal link directly, reporters correlate earth and weather time and again. In Victorian and Edwardian newspaper articles, earthquakes are at times also discussed as possibly, though inconclusively, linked to the moon, to magnetism, to aurora, to the earth's molten core, to the impact of sodium and potassium deposits, weather, plants and animal movements. Claims for absolute knowledge of earthquakes are treated with suspicion. In these tiny interstices of doubt, at the edge of science's reach, we are offered a humility. Pause.

The resistance of earthquakes to mapping, and reporters' responsiveness to this resistance, is helpfully contrasted by Carter's analysis of cartographers' linear representations of coastline - theirs is a "hard and dry" representation of the world (2009: 50, 8). Carter argues that the boldness of colonial mapping of coastline, despite the indeterminacy of land's interpretation and form, provided "a rhetorical solution to the problem of getting on" (61). Although our colonial earthquake reporters surely must have had similar hope of 'emancipation', any such dreams are constantly shaken off by the very phenomena they try to map.

In this way, earthquakes thwart dreams of human control over their environments. The quaking earth refuses the configuration of land as palimpsest. Attempts, however, have certainly been made to control earthquakes: when faced with the 1812 earthquake in Caracas, Simon Bolivar is claimed to have said the famous words, "If Nature is against us, we shall fight against Nature and make it obey." Bolivar, in keeping with the thinking of the time, was convinced that "Nature could be dominated" (Acosta 2010). In New Zealand, architect Thomas Turnbull offered the hope that human civilisation 
would civilise the land, leading to a calming of earthquakes like those that had rattled Wellington in 1848. Such promise of emancipation from Nature is a fundamental promise of the story of modernity, an emancipation which, Latour argues, we have never, and could never, really achieve (2010: 74).

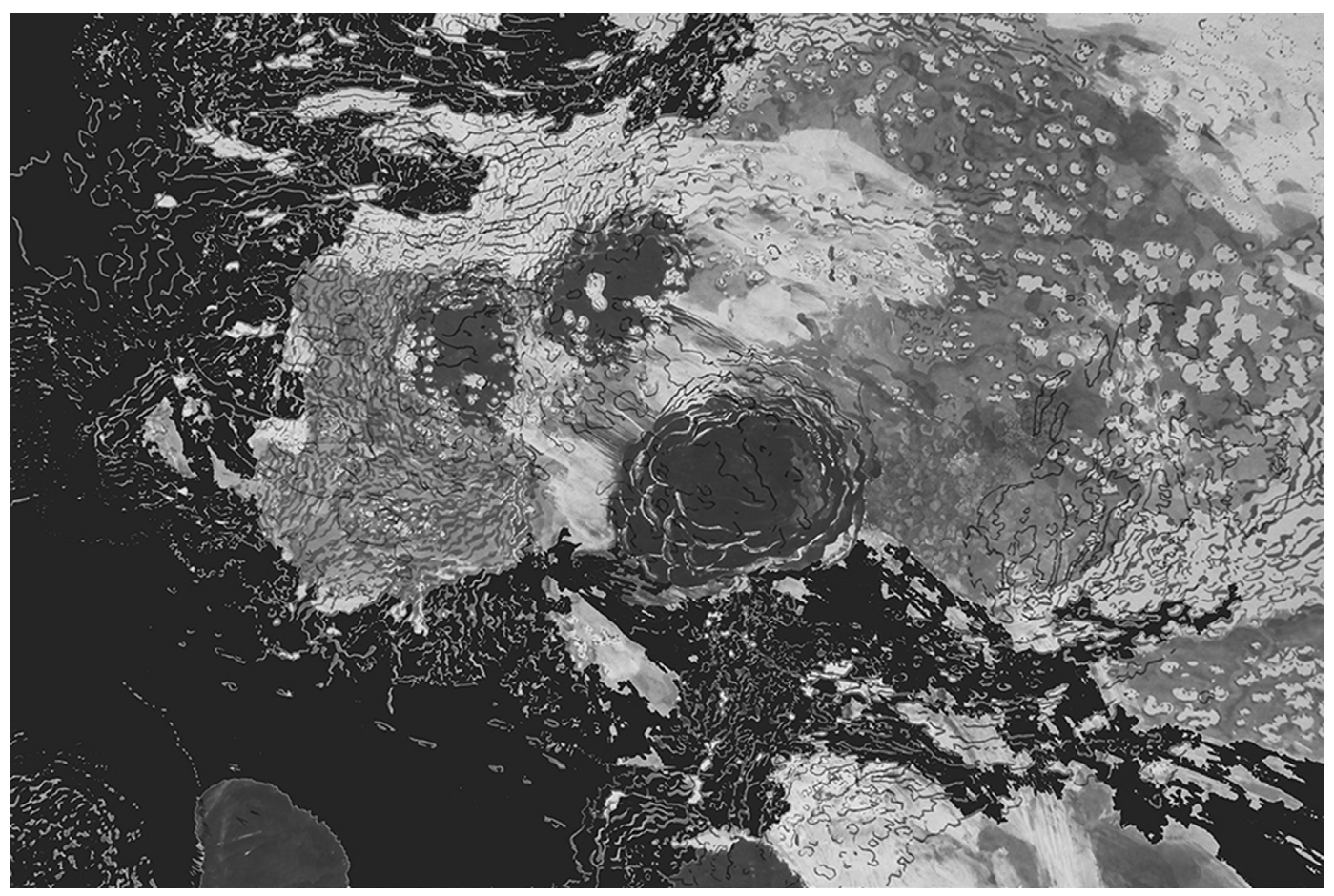

Fig. 5 Report from the Wanganui Chronicle, 1881: "Perhaps the heaviest and most severe shock of earthquake that has been experienced in this town for the last 25 years occurred on Sunday morning, about 5.23 o'clock. The weather at the time was extremely boisterous, a strong south-east gale blowing, accompanied by smart showers of rain.... One peculiarity of this earthquake was that, though previously the night was pitch dark, yet during the agitation it was possible to discern with some distinctness objects at a distance of some yards, and when the quaking ceased the night became as dark as before.” (1881, 27 June)

\section{Earthquake correspondences and écriture féminine}

The earthquake correspondents' reports, humble and tentative as they are, seem to suggest the possible existence of less dominating modes of relating to nature, even in the midst of aggressive colonisation. For Cixous, societal earthquakes encourage (or demand) the non-domination of écriture féminine or feminine writing:

Sometimes ... it is the fissure made by an earthquake, when material upheaval causes radical changes in things, when all structures are momentarily disoriented and a fleeting savagery sweeps order away, that the poet lets women pass through for a brief interval. (1997: 170)

Though, here, Cixous specifically mentions women, generally she does not define feminine writing by the sex of the author but, rather, by what she defines as a feminine subject position, a refusal to forge for oneself a position of mastery through the appropriation or annihilation of another's differences (1994: xxxix). The correspondents whose reports feature in this paper are unable to comfortably theorise the experience of earthquake, and yet they allow associations and parallels between earthquake and weather to remain. In this way, they participate in feminine writing, through which they become poets of what Cixous refers to as "the most true", the "not stoppedstoppable" (Cixous \& Calle-Gruber 1997: 4). She argues that: 
All that is stopped, grasped, all that is subjugated, easily transmitted, easily picked up, all that comes under the word concept, which is to say all that is taken, caged, is less true ... Each object is in reality a small virtual volcano. There is a continuity in the living; whereas theory entails a discontinuity, a cut, which is altogether the opposite of life. (4)

Such works, like Cixous' own writing, participate in what Jane Hiddleson has described as the "genre of theory, but allow the object of their theorising to shift and mutate, in their enjoyment of poetic associations, parallels and allusions" (2010: 51). In such a manner, rather than being tied to explicit hypotheses, the earthquake weather correspondences offered by anonymous reporters, tentatively associate earth and weather movement with a general silence about the nature of their relationship. There are no bold hypotheses explaining the earth's relation to weather, no great claims of prophetic knowledge of the earth's movement; rather, poetic pairings of earth movement and weather stillness emerge alongside moments of doomed weather and earthquake. In the face of an earthquake, earth becomes weather, moving and uncontrollable. The small moments of weather anamnesis offered by earthquake correspondents, the "I'm-not-sure-if-it-matters" offerings of non-domination somehow render these moments more deeply sensible. Tiny moments of the continuity of living are offered.

Peggy Kamuf reminds us that, "[w]e say a matter is grave to remind ourselves to ponder it, to weigh it carefully, to exercise acute ethical vigilance"; to such matters, we typically take the approach that, "[i]f the matter is grave, then, by definition it should not be taken lightly" (1995: 68). Yet, following Cixous, Kamuf stresses that, particularly when a matter is grave, the "most responsible and serious approach advances carefully and slowly, but above all lightly - which may mean obliquely, or imperceptibly, or even not at all" (68). Aspects of this (ultimately unattainable) lightness are apparent in the work of the correspondents. Possibilities of correlation are always given ample room to escape; weather and earthquake movement find mention in same breath, again and again in the reports, though never with an explanation of what they might be doing so close together.

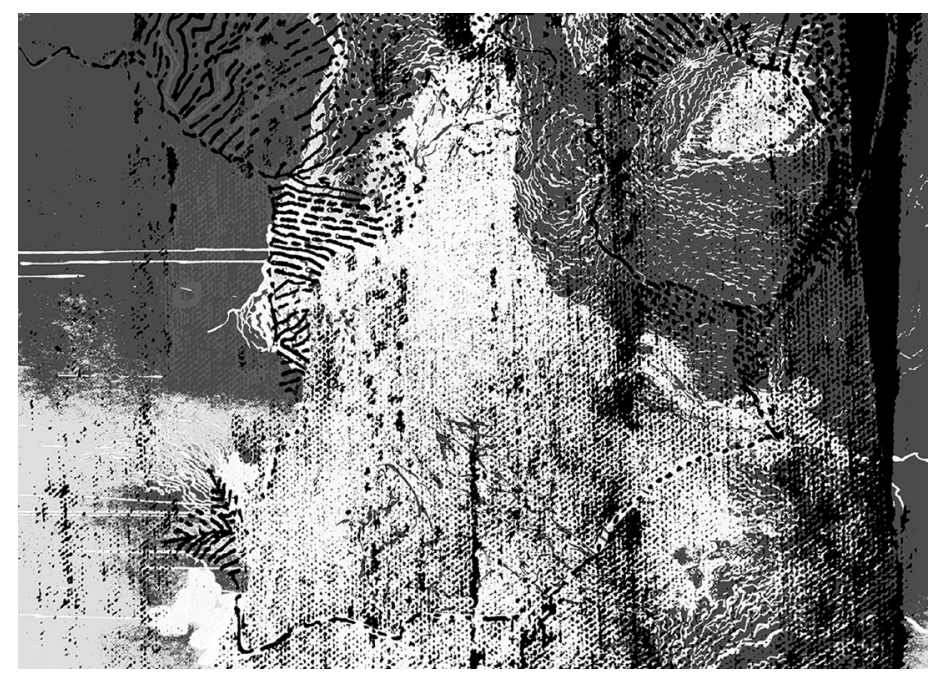

Fig. 6 "Some of the inhabitants of Port Chalmers ... appear to have been greatly alarmed by the [earthquake's] occurrence. ... Several of the houses were shaken, windows rattled violently, and the bottles and jars in some of the shops and stores were started from their places. About 50 tons of spalls for concrete for the Graving Docks, which were on an angle of 60 degrees, were set in motion by the concussion, and rolled down the hill side. The men at work underneath got clear in time. The wave seemed to come from the north-east. The weather was quite calm at the time of the occurrence."(1869, 25 June)

Resonating with Kamuf's remarks on the love note, in which one does not wish to crush one's lover under the weight of one's own desires, Victorian and Edwardian correspondents of earthquakes 
and weather offer, time and time again, paths of escape. In this way, the delicate relationships suggested in the reports offer generous spaces of possibility.

Isabelle Stengers' (2005) cosmopolitics asks for a holding up of proceedings, a slowing down, always asking whether there might not be something else more important. Such a hold-up offers, for example, room for the consideration of those who would not participate in decisions, or who cannot. Stengers frames cosmopolitics as a matter of:

... imbuing political voices with the feeling that they do not master the situation they discuss, that the political arena is peopled with shadows of that which does not have a political voice, cannot have, or does not want to have one. (2005: 996)

Such quiet approaches are not attempts to speak for the earth or the earth's movement (a ventriloquism which promises only that the other will be subsumed and old exclusions reinscribed). Rather, they offer a pause. Echoing Kamuf, but with the temporal (rather than the weighty) as her metre, Stengers adds that this slowing up is not a denial of urgency, rather it is a refusing to stop thinking that "there is something more important", even in the face of the urge to hurry (994).

The images in this paper record earthquake weather by creating pauses in conglomerating matter and emotions. Addressing similar concerns, digital media artist Andrea Polli, in her project Particle Falls, a large scale, real-time visualisation of air-quality data, gathers together air quality, public projection and anxiety about bodily health, expressing their relationship in terms of uncertainty: "Air - it's invisible. We can't really see it, touch it, know that it exists ... How can we become more aware of what's happening with our air before we experience asthma or other problems that come from bad air?" (“Particle falls” 2013). In a similar vein, Gavin Baily, Tom Corby and Jonathan Mackenzie use real-time scientific data as communicative and cultural phenomena in their work, Southern Ocean Studies: "The Southern Ocean Studies are part of a series of projects which aims to explore how Climate Models can function as representations of climate change beyond their original scientific contexts and purpose, i.e. as art media with expressive, conceptual and critical potential" (Southern Ocean Studies" 2009). The images of slow circulation of water and biotic forms in the Southern Ocean Studies proffer knowledge to be received also as visual gift. The digital record of the flickering data freeze frames and a quiet resumption of movement is longingly anticipated.

Perhaps the earth herself, in her refusal to be fully predicable, shapes the looseness of contemporary and the nineteenth century reports. The spaces created in the slowness and the pauses, in the interstices between disciplines and ways of understanding, resist calls to formulate how to proceed. They are also interstices of fertility. Public space is given over to uncertainty; what is unknown cannot be stated. Hurried attempts at solution-forming are stalled, and tiny public offerings to indeterminacies arise, suggesting that, if the threat of quackery or violent persuasion is to be averted, space must be held open for humility and wondering about what else might matter (whether we can ever know it). And so, just for a moment, earthquake weather correspondents, in ways that resemble some artists' weighty indeterminacies, offer a slowing-up, a refusal to destroy an unknown through writing, as they merely (and massively) hold up proceeding-as-normal, for just a moment. 


\section{References}

(1851, August 2). Journal of the week. Lyttelton Times, 5.

(1855, January 24). Local intelligence. Lyttelton Times, 5.

(1855, November 21). California. Taranaki Herald, 3.

(1868, December 24). An earthquake in England. Star, 3.

(1869 25 June). The earthquake. Otago Daily Times (2305), 2.

(1881, 27 June). The earthquake. Wanganui Chronicle, XXIII(9437), 2.

(1885, January 16). Shock of earthquake. Star, 4.

(1885, September 5). The earthquake shocks in Calcutta. Otago Daily Times, p. 1.

(1893, February 23). Earthquakes. To the editor. Evening Post, 3.

(1894, April 3). Earthquake. Press, 5.

(1902, April 9). Heavy gales. Fielding Star, 2.

(1902, May 17). In earthquake shock Otago Daily Times, 8.

(1904, August 10). Severe earthquake shocks. Oamaru Mail, 2.

(1907, April 20). Earthquake and thunderstorm. Otago Daily Times, 10.

(1908, 8 December). Forecasting earthquakes. Wanganui Chronicle, L (12145), 4.

(1909, February 5). Astronomical notes for February. Wairarapa Daily Times, 7.

(1918, December 17). Earthquake weather. Evening Post, 11.

(1919, 10 May). Earthquakes: Influences on weather. Evening Post, XCVIII(109), 11.

(2009). Southern ocean studies. Reconnoitre. Retrieved from http://www.reconnoitre.net/bas/

(2013). Particle falls: Public art by Andrea Polli. Sensing Change. Chemical Heritage Foundation. Retrieved from http://sensingchange.chemheritage.org/sensing-change/art/particle-falls

Acosta, A. (2010). Toward the universal declaration of rights of nature, thoughts for action. AFSE Journal. Retrieved in unpaginated form from http://therightsofnature.org/wp-content/uploads/pdfs/Toward-the-Universal-Declarationof-Rights-of-Nature-Alberto-Acosta.pdf.

Arnold, T. (1861). Reminiscences of New Zealand. Frazer's Magazine (August), 254.

Böhme, G. (2005). Atmosphere as the subject matter of architecture. In P. Ursprung (Ed.), Herzog and De Meuron: Natural history (pp. 398-406). Montréal, Canada: Lars Müller Publishers.

Böhme, G. (2013). The art of the stage set as a paradigm for an aesthetics of atmosphere. Ambiances. Retrieved from http://ambiances.revues.org/315.

Carter, P. (2009). Dark writing: Geography, performance, design. Honolulu, HI: University of Hawai'i Press.

Cixous, H. (1994). The Hélène Cixous reader. Oxford, UK: Routledge.

Cixous, H. (1997). Sorties: Out and Out: Attacks/Ways Out/Forays. In A. D. Schrift (Ed.), Logic of the gift: Toward an ethic of generosity (pp. 148-173). New York, NY: Routledge.

Cixous, H. (2012). Portraits of portraits. In M. Segarra and J. Masó (Eds.), Poetry in painting: Writings on contemporary arts and aesthetics. Edinburgh, UK: Edinburgh University Press.

Cixous, H., \& Calle-Gruber, M. (1997). Rootprints: Memory and life writing. London, UK: Routledge.

Didion, J. (2008). Slouching towards Bethlehem: Essays. New York, NY: Farrar, Straus and Giroux.

Diller, E. (2001). Blur/babble. Anything, 132-139.

Evans, S. (2011). Christchurch earthquake - New Zealanders begin to count the cost. World Posts Plus News Service. Retrieved from http://wppts.com/christchurch-earthquake-new-zealanders-begin-to-count-the-cost/365921/

Hiddleson, J. (2010). Poststructuralism and postcoloniality. Liverpool, UK: Liverpool University Press.

Hill, J. (2012). Weather architecture. Abingdon, UK: Routledge Chapman \& Hall.

Ingold, T. (2008). Bindings against boundaries: Entanglements of life in an open world. Environment and Planning $A(40), 1796-1810$.

Ingold, T. (2010). Foot-prints through the weather-world: Walking, breathing, knowing. Journal of the Royal Anthropological Institute, S121-139.

Kamuf, P. (1995). To give place: Semi-approaches to Hélène Cixous. Yale French Studies, 87, 68-89.

Latour, B. (2010). A plea for earthly sciences. In J. Burnett, S. Jeffers and G. Thomas (Eds.), New social connections: Sociology's subjects and objects (pp. 72-85). Chippenham and Eastbourne, UK: Palgrave McMillan.

Stengers, I. (2005). The cosmopolitical proposal. In B. Latour and P. Webel (Eds.), Making things public (994-1003). Cambridge, MA: MIT Press.

Stengers, I. (2010). Cosmopolitics 1 (R. Bononno, Trans.). Minneapolis, MA: University of Minnesota Press. 


\section{Endnotes}

${ }^{1}$ A severe earthquake of magnitude 6.2 was experienced in the Wellington region on January 20th 2014, at 3.52pm. See http://www. geonet.org.nz/quakes/region/wellington/2014p051675 